\title{
Multidimensional Labelling: Closing the Sustainability Information Gap between Producers, Consumers and Sustainability Science in the Food Sector
}

\author{
Tamás Kocsis ${ }^{1 *}$, Béla Kuslits ${ }^{1}$ \\ 1 Institute of Geography, Geoeconomy and Sustainable Development, Corvinus University of Budapest, \\ H-1093 Budapest, Fővám tér 8., Hungary \\ *Corresponding author, e-mail: tamas.kocsis@uni-corvinus.hu
}

Received: 29 May 2018, Accepted: 04 December 2018, Published online: 28 January 2019

\begin{abstract}
Product labels are designed to diminish producer-consumer information asymmetry, which represents a typical information gap. However, sustainability science, in its broadest sense, is another 'agent' for achieving sustainable development, while producer-science and consumer-science information gaps can also be identified. As a step towards closing these gaps, we propose a multidimensional form of eco-labelling in the food sector: a well-chosen system of labels that refer to the possible trade-offs known to sustainability science. The dimensions proposed in our model reflect types of negative environmental effects: the entities harmfully affected by production may be (1) other, non-human species (OTHER; 0th party), (2) other people thousands of miles away in space (FARTHER; 1st party), (3) consumers themselves in the present (HERE; 2nd party), or (4) other people later in time (LATER; 3rd party). We apply this framework to ethical labelling in the food sector.
\end{abstract}

Keywords

ecolabels, environment, food sector, multidimensionality, sustainability, trade-off

\begin{abstract}
1 Introduction
Sustainability science "as a problem-driven discipline... is concerned with addressing practical challenges caused by climate change, habitat and biodiversity loss, and poverty among others. At the same time, it tries to investigate root causes of problems by generating new knowledge or structuring current knowledge systems in a holistic way to enhance understanding of global sustainability." (Takeuchi, 2017; see also Clark, 2007) These challenges also involve trade-offs between global and local problems, indicating the multidimensional nature of the sustainability problem (see e.g. Steffen et al., 2015; Gupta, 2017).

The most important components of sustainability science for us are the visions and frameworks offered by ecological economics and strong sustainability. According to this approach, our Earth is a materially limited system in which unlimited economic growth is logically impossible (Daly, 1996), which is also a well-known position within the emerging Degrowth movement (Schneider et al., 2010). When choosing analytical boundaries adequately, we are often confronted with these limits. Global climate change in time, unfair trade in (geographical) space, or
\end{abstract}

the unfair treatment of animals in terms of level of relationship are all examples of how production occurs in a system with limited material resources. Making gains (cost-saving) in one problem dimension may create costs in another (i.e. trade-offs).

However, this paper does not address sustainability science itself, but its consequences. What can be derived from such scientific knowledge about the everyday decisions of billions of consumers and producers on Earth? As is generally true, (1) producers do not know exactly how to produce in a sustainable way, and (2) consumers do not know exactly what to buy to be sustainable - lacking state-ofthe-art natural scientific knowledge about sustainability. These two information gaps are additional to the classical one described by economics, namely that (3) information asymmetry is a market failure between producers and consumers (Verbeke, 2005). This complex of uncertainty around information and sustainability will be referred to later in brief as the sustainability information gap.

According to Gallastegui, labels are designed to fill the information gap about the social and environmental 
side-effects of production and consumption which would otherwise remain in the shadows. Labels are also perceived as brands, thus the information they provide is not limited to information about products, but represents a more complex set of values, information, social pressures, etc. (Gallastegui, 2002). For the purpose of the research described herein, we understand eco-labelling to signify that "concise, specific measures have been taken by the producer in order to avoid or limit, undesirable externalities on the ecosystem and the environment" (Boude et al., 2005; quoted by Erwann, 2009:p.251), and where the notion 'environment' embodies social issues as well.

We suggest that different environmental dimensions should be constructed to enable a focus on specific ethical dilemmas regarding product sustainability. Although not always, differently labelled products typically confront consumers with a similar dilemma: they emphasize one key attribute of the production process (this is the "Sin of Hidden Trade-Off" among the Seven Sins of Greenwashing - Terrachoice, 2010) and invite buyers to choose the "more ethical" alternative. But, as de Jonge and her colleagues claim, most labelling schemes have the effect of presenting binary choices (organic or non-organic, fairly traded or not, etc.) while consumers may prefer more nuanced choices. If these choices were not between two extremes, fewer consumers would end up choosing 'the worst' option (de Jonge et al., 2015). One potential answer to managing this higher complexity is the multi-levelling approach proposed by Weinrich and Spiller (2016); another is the multidimensional approach described in this paper. The combination of both concepts may lie far in the future (see also Dendler, 2014), but as an orientation and as a logical and theoretical frame may yet play an important role in future decisions and policy making.

According to a review of literature by Prieto-Sandoval et al. (2016), the most often-cited authors in product labelling are engaged in researching issues related to the food sector (Blend and Van Ravenswaay, 1999; Loureiro et al., 2001; Loureiro and Hine, 2002). Thus, to construct our multidimensional labelling approach we use examples from the food sector.

We structure our theoretical position in four steps involving: (i) a review of the notions of eco-innovation and eco-labelling in the food sector; (ii) definition of the sustainability information gap; (iii) a suggestion for label dimensions; and then (iv) the sketch of the main lines of the proposed system of multidimensional labelling. Finally, we summarize our conclusions.

\section{Defining the sustainability information gap}

Dangelico and Pujari (2010) and Wagner (2008) interpret eco-labelling as an eco-innovation process because it promotes the emergence of new green products and improves production methods, supply sources and combinations (Hellström, 2007). It is important to note that this is an effect at the organizational level that is transmitted along the value chain. However, the impact of eco-labelling goes beyond organizational borders and affects consumer awareness and governmental and institutional regulations in an interactive way in which each agent influences others, creating the virtuous circle described by PrietoSandoval et al. (2016). Among the agents of this virtuous circle, state-of-the-art science should be incorporated, as the issue of sustainability is far from being static.

Scientific information is also crucial: as Grunert et al. (2014) confirm, sustainability labels still do not play a major role in consumers' food choices, but future use of these labels will depend on consumers' general concerns about sustainability. The recent publication of an environmental labelling standard adds a new dimension to food labelling and declarations (ISO, 2016). A multidimensional labelling system which reflects scientific facts about sustainability would be useful in teaching consumers, and of course producers, about the interrelationships between all the components of our materially closed world (i.e. foster a systems-approach - van den Bergh, 2010).

Thus, we regard eco-labels as useful agents for reducing information asymmetry (Akerlof, 1970; Antle, 2001; Darby and Karni, 1973; Nelson, 1970). Producers usually have more information about their products than consumers do. However, information gaps exist in relation to both 'producers and sustainability science' and 'consumers and sustainability science' regarding the complicated nature of sustainability. This we call the sustainability information gap (Fig. 1).

Process attributes (e.g. animal welfare and sustainability) are credence attributes which consumers cannot

\section{SUSTAINABILITY SCIENCE}

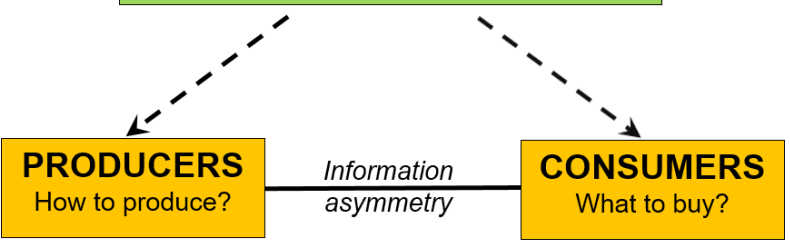

Fig. 1 The sustainability information gap (Note: The line and the two arrows represent potential information gaps between the participants of the sustainability problem) 
verify when purchasing finished goods (Darby and Karni, 1973). Therefore, as Weinrich and Spiller (2016) state, labels help consumers who may be looking for hidden process or product attributes by transforming credence goods into search goods (Caswell and Mojduszka, 1996; Caswell and Padberg, 1992; Jahn et al., 2005).

\section{From eco-labelling to multidimensionality in the food sector}

There are numerous methods and models which have been specifically developed and adapted to the planning, processing activities and control of the food sector, from farm to retail and household. The focus is not only on reducing costs, but also on fostering sustainability and preserving the environment (Akkerman et al., 2010; ManziniAccorsi, 2013; Battini et al., 2014; Djekic et al., 2018).

Eco-labelling is of strategic use in diminishing information asymmetry between the producers and consumers of a (food) product. According to Prieto-Sandoval et al. (2016), the diversity of ecolabels fostered the institutional standardization of the principles of eco-labelling in ISO 14020:2002. ISO later proposed three categories of environmental labels according to the features they cover and the rigor required for obtaining the qualification: Type I in ISO 14024; Type II in ISO 14021; and Type III in ISO 14025. An additional category called "Type I like" is also described in the literature, which represents environmental labels focused on a single environmental or social feature; these labels have been launched by independent organizations (Leire and Thidell, 2005; Panainte et al., 2014). These environmental or social features will be regarded here as the dimensions in which the negative external effects of production arise.

One potential way of increasing the efficiency of labelling has been proposed by Weinrich and Spiller (2016) who claim that a clear, multi-level labelling scheme increases willingness to pay (WTP) for products produced using higher standard technologies (see also Fischer and Lyon, 2014). However, in addition to this concept, we propose a multidimensional system.

For constructing a general theoretical frame we use EPA's sustainability definitions and terms about first, second and third party. "These terms describe a person or organization's relationship to a product or organization. The first party is the organization, and provides the object. The second party is usually a person or organization that the first organization interacts with. The third party is a person or body that is independent of the first and second party." (EPA, 2018). By stepping over the boundaries of our anthropocentric world-view we add a novel but important party to these in the food sector: animals, or more generally, non-human beings. Accepting their special status we refer to them as zeroth party (Table 1).

\section{Possible label dimensions in the food sector}

In the following we summarize some real-world cases of the labelling of food products to illustrate the potential to integrate them into dimensions of a multidimensional labelling concept. Square brackets at the beginning of the paragraphs contain the names of the dimensions used later in our model (see Table 1).

0. [OTHER] Animal welfare, alongside anthropocentric welfarism (Johansson-Stenman, 2018), is an important specific category where labels play an important role and invokes a significant emotional response in a fraction of consumers. Similarly to with other labels, a subset of consumers is willing (even determined) to pay a higher price for products associated with higher animal welfare (Bennett, 1997). On the other hand, many consumers think that the mainstream treatment of animals is sufficiently ethical - a belief that may partly be based on a lack of detailed information about wide-spread animal rearing practices. The provision of more information about animal treatment by producers to these consumers increases their WTP for labelled meat products (Napolitano et al., 2008).

1. [FARTHER] Fair-trade schemes signal the existence of trade partnerships that promote sustainable (economic) development opportunities for disadvantaged producers worldwide (De Pelsmacker et al., 2006). Similarly to consumers who favor organic products, buyers of fairly traded products are somewhat price sensitive, but a significant fraction of them are strongly value driven and express considerable price elasticity in favor of more ethical products. It is also clear that some fair-trade consumers select these products not only for ethical reasons, but because

Table 1 The general system of ethical labelling in the food sector (Note: Our proposed system logically covers all possible 'stakeholders' of the food sector bearing harmful effects in the form of external costs - Kerekes et al., 2018:pp.170-173)

\begin{tabular}{llcc}
\hline dimension & subject & example & referred as ... \\
\hline $0^{\text {th }}$ party & Animals & $\begin{array}{c}\text { The product is } \\
\text { ethically farmed } \\
\text { The product is } \\
\text { fair-traded }\end{array}$ & OTHER \\
$1^{\text {st }}$ party & Producers & FARTHER \\
$2^{\text {nd }}$ party & Consumers & $\begin{array}{c}\text { The product is } \\
\text { GMO-free }\end{array}$ & HERE \\
$3^{\text {rd }}$ party & $\begin{array}{c}\text { Future } \\
\text { generations }\end{array}$ & $\begin{array}{c}\text { The product is } \\
\text { carbon-neutral }\end{array}$ & LATER \\
\hline
\end{tabular}


they believe that fairly traded products are of higher quality. Commonly, however, fair-trade labels indicate greater accountability at the end of the supply chain: a potentially significant geographical distance (Arnot et al., 2006), where distance can be understood even in its cultural or other sense (Princen, 1997).

2. [HERE] In this scenario the consumer personally bears the cost externalized. It is an important research question how consumers decide whether to accept the consequences themselves or shift costs to others. For example, consumers' WTP for GMO (genetically modified organisms)-free products are significantly higher than for GMO-containing products (Noussair et al., 2004). We do not seek to discuss the scientific evidence about the health effects of genetically modified products in this paper. Regardless of the medical evidence, consumers often perceive these products as harmful or risky and are willing to pay higher prices to avoid the perceived risk (Grunert, 2005; Kimenju and De Groote, 2008; Loureiro and Hine, 2002; Hlédik and Lógó, 2017).

3. [LATER] Climate change is one of the most prominent sustainability issues (Balint et al., 2017), although there is no established label for 'low-carbon' products in the food sector. A few studies have been conducted to explore consumer WTP for climate-friendly products. In some cases, a low but significant WTP for low-carbon products has been found (Koistinen et al., 2013; Feucht and Zander, 2018), but other research indicates that there is no WTP, suggesting low interest in this topic (Vanclay et al., 2011; Zhao et al., 2018). However, multi-levelling in the form of a "traffic light" color scheme has been successfully tested (Thøgersen and Nielsen, 2016). Among the explanations for this are that no beneficiaries can be clearly identified from such product choices, and that a global issue such as climate change may be perceived as abstract by individual consumers (Röös and Tjärnemo, 2011). Of course, this dimension generally applies to any case where the human sufferer of a harmful impact is independent of the producer or the consumer of a product (3rd party).

\section{Towards a system of multidimensional labelling in the food sector}

In the case of food labels, according to Lang and Heasman (2015), there are two extremes: "productivity", and "ecology". Competition between the two results in polarizing debates, such as "food wars". In fact, agricultural and food processing and packaging conditions are much more differentiated than these two contrary constructs. Thus, a multi-level system may better describe this problem as it uses more than two items (Weinrich and Spiller, 2016). These levels may be multiplied by level of connectedness (OTHER) the environmental dimensions of (geographical) space (FARTHER), time (LATER) (see also WTP for three types of sustainability labels in Vecchio and Annunziata, 2015) and the quality and standard criteria of impacts on consumers of the product itself (HERE) (see Section 4). Synchronous use of these dimensions is the concept of multidimensional labelling (Fig. 2).

This naturally results in a more complicated system of labelling, but, on the other hand, increases clarity regarding the complexity of sustainability issues. At this point, market segmentation should also be discussed. According to a suggestion by Weinrich and Spiller (2016), financial benefits may increase with the introduction of a multi-level label. However, if product quantities are too small, costs may rise along the whole value chain (see the term "oversegmentation" in Kotler and Bliemel, 2001). Nevertheless, to determine the optimal level of market segmentation, gains must be appraised. In the case of extending the multi-levelling system to include multi-dimensionality, the importance of the above-described issue cannot be overstressed.

Even 'pure' multi-levelling may somewhat complicate consumer decisions. Due to the typical lack of time buyers have in a shopping situation (see also the concept of "information saturation" in Süle, 2012), Feunekes et al. (2008) recommend the use of simpler labelling systems. This suggestion is supported by a review article of

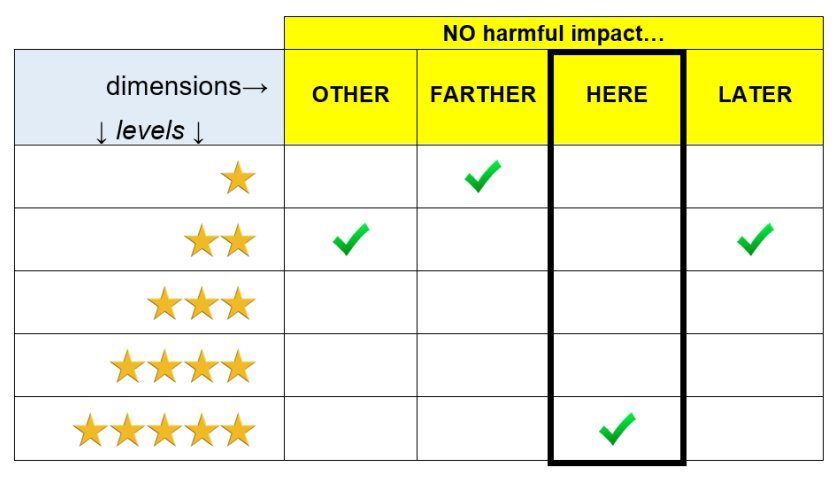

Fig. 2 A matrix indicating a hypothetical, multi-level, multidimensional eco-labelling system. (Note: Each dimension has its own qualification level. Checkmarks are included to provide an arbitrary example of the evaluation of a specific product. For example eggs can have the highest nutritional quality for the consumer/HERE/ while hens are kept in a closed building without natural light/OTHER/, the whole cost of the eggs is not paid to the producer /FARTHER/, and fossil fuels are used for heating the rooms and delivering the eggs /LATER/) 
Grunert and Wills (2007) which finds that consumers like the idea of having simplified information on the front of their product packages. Further, findings show that confusion increases with the complexity of information contained in Guidelines Daily Amounts (GDA) scores related to nutrition labelling, technical terms, numerical calculations, and, for some consumers, percentages (Van Kleef and Dagevos, 2015; Weinrich and Spiller, 2016). Thus any complex, multi-levelled and/or multidimensional labelling system must be as easy to interpret as possible, while the inherent environmental trade-offs of purchasing decisions should not be obfuscated. The use of simple, well-recognized and accepted pictograms indicating different environmental dimensions may help solve this problem as well as sophisticated use of new information and communication technologies (ICT; Hepting et al., 2014).

Thus in a research effort different types of basic information rooted in real-world cases could be used which can serve as the background for labels regarding specific environmental dimensions. We hypothesize that a difference in consumer evaluations of various types of environmental impacts would be reflected in our multidimensional labelling model: while on the production side cost externalization lead to economic gains, it is assumed that consumers might judge these gains differently according to the nature of the externalization process. (i.e. we suppose that making a gain for a producer would create a cost somewhere else in the system).

\section{Conclusion}

Our study is partially inspired by the concept of multilevel labelling (Weinrich and Spiller, 2016). However, this important idea may be further accomplished through taking a second step by which the inherently multidimensional nature of sustainability is reflected. This step must be taken in a well-structured, easy-to-understand, internationally known and accepted manner, thereby helping to create a more sustainable world. Multidimensional labelling could help reduce consumers' cognitive challenges with making ethical decisions in product purchase situations, as well as help understand company decisions regarding greening the process and structure of production while avoiding the Sin of Hidden Trade-Offs.

It is an important ethical question how and to what extent economic interactions have harmful side effects. In a full and a materially closed world, an idea that the
Degrowth movement, ecological economics and state-ofthe-art sustainability sciences promote, ecological carrying capacity is limited. Thus, even when the harmful external consequences of a production process are not accounted for, this still causes harm (external cost), making the wider system unsustainable. The proposed multidimensional labelling system may represent a good development for handling the problem of complexity within the concept of sustainability. Using multidimensional labelling as a theoretical frame we could be able to confront consumers and producers with different ethical issues in the food sector which can be a fruitful research project.

Our model about the multidimensional eco-labels may contribute to the development of more efficient policies and better business strategies that support sustainable production and consumption in accordance with the state-ofthe-art knowledge of sustainability science. The proposed system of multidimensional product labels may help with informing and teaching consumers about the ethical content of their purchasing decisions, reveal to producers the complex impact of decisions about production process, and clarify the relationship between product prices and the features certified by eco-labels.

We believe that the use of a purposeful, multidimensional system of eco-labels can diminish not only the information asymmetry between 'producers and consumers' but also the information gaps between 'sustainability science and producers' and 'sustainability science and consumers' as defined in the concept of the sustainability information gap. Eco-labels ordered along different social and environmental dimensions include the complex message of sustainability by structure. In this theoretical frame, development is often paired with social and environmental trade-offs. Multidimensional labelling may represent an important step towards reducing the related information gaps and a small, but definite step towards creating a more sustainable world.

\section{Acknowledgement}

This work was supported by the Hungarian National Research, Development and Innovation Office - NKFIH, OTKA [120183]. 


\section{References}

Akerlof, G. A. (1970) "The Market for "Lemons": Quality Uncertainty and the Market Mechanism", The Quarterly Journal of Economics, 84(3), pp. 488-500. https://oi.org/10.2307/1879431

Akkerman, R., Farahani, P., Grunow, M. (2010) "Quality, safety and sustainability in food distribution: a review of quantitative operations management approaches and challenges", OR Spectrum, 32(4), pp. 863-904.

https://doi.org/10.1007/s00291-010-0223-2

Antle, J. M. (2001) "Chapter 19 Economic analysis of food safety", In: Handbook of Agricultural Economics, Vol. 1, Elsevier, pp. $1083-1136$ https://doi.org/10.1016/S1574-0072(01)10027-7

Arnot, C., Boxall, P. C., Cash, S. B. (2006) "Do Ethical Consumers Care About Price? A Revealed Preference Analysis of Fair Trade Coffee Purchases", Canadian Journal of Agricultural Economics, 54(4), pp. 555-565.

https://doi.org/10.1111/j.1744-7976.2006.00066.x

Balint, T., Lamperti, F., Mandel, A., Napoletano, M., Roventini, A., Sapio, A. (2017) "Complexity and the Economics of Climate Change: A Survey and a Look Forward", Ecological Economics, 138, pp. 252-265. https://doi.org/10.1016/j.ecolecon.2017.03.032

Battini, D., Persona, A., Sgarbossa, F. (2014) "A sustainable EOQ model: Theoretical formulation and applications", International Journal of Production Economics, 149, pp. 145-153. https://doi.org/10.1016/j.ijpe.2013.06.026

Bennett, R. M. (1997) "Farm animal welfare and food policy", Food Policy, 22(4), pp. 281-288. https://doi.org/10.1016/S0306-9192(97)00019-5

Blend, J. R., Van Ravenswaay, E. O. (1999) "Measuring Consumer Demand for Ecolabeled Apples", American Journal of Agricultural Economics, 81(5), pp. 1072-1077. https://doi.org/10.2307/1244086

Boude, J. P., Charles, E, Gouin S. (2005) "Label qualité et écolabel dans la pêche artisanale" (Quality and ecolabel in small-scale fishers' catch), Série rapport no R-03-2005, Publications Amure. (in French)

Caswell, J. A., Mojduszka, E. M. (1996) "Using Informational Labeling to Influence the Market for Quality in Food Products", American Journal of Agricultural Economics, 78(5), pp. 1248-1253. https://doi.org/10.2307/1243501

Caswell, J. A., Padberg, D. I. (1992) "Toward a More Comprehensive Theory of Food Labels", American Journal of Agricultural Economics, 74(2), pp. 460-468. https://doi.org/10.2307/1242500

Clark, W. C. (2007) "Sustainability Science: A room of its own", Proceedings of the National Academy of Sciences of the United States of America, 104(6), pp. 1737-1738. https://doi.org/10.1073/pnas.0611291104

Daly, H. E. (1996) "Beyond Growth: The Economics of Sustainable Development", Beacon Press, Boston, MA.

Dangelico, R. M., Pujari, D. (2010) "Mainstreaming Green Product Innovation: Why and How Companies Integrate Environmental Sustainability", Journal of Business Ethics, 95(3), pp. 471-486. https://doi.org/10.1007/s10551-010-0434-0
Darby, M. R., Karni, E. (1973) "Free Competition and the Optimal Amount of Fraud", The Journal of Law \& Economics, 16(1), pp. 67-88.

de Jonge, J., van der Lans, I. A., van Trijp, H. C. M. (2015) "Different shades of grey: Compromise products to encourage animal friendly consumption", Food Quality and Preference, 45, pp. 87-99. https://doi.org/10.1016/j.foodqual.2015.06.001

De Pelsmacker, P., Driesen, L., Rayp, G. (2006). Do consumers Care about ethics? Willingness to pay for fair-trade coffee. Journal of Consumer Affairs, 39(2), pp. 363-385.

https://doi.org/10.1111/j.1745-6606.2005.00019.x

Dendler, L. (2014) "Sustainability Meta Labelling: An effective measure to facilitate more sustainable consumption and production?", Journal of Cleaner Production, 63, pp. 74-83. https://doi.org/10.1016/j.jclepro.2013.04.037

Djekic, I., Sanjuán, N., Clemente, G., Režek Jambrak, A., DjukićVuković, A., Brodnjak, U. V., Pop, E., Thomopoulos, R., Tonda, A. (2018) "Review on environmental models in the food chain - Current status and future perspectives", Journal of Cleaner Production, 176, pp. 1012-1025. https://doi.org/10.1016/J.JCLEPRO.2017.11.241

EPA (2018) "Glossary of Sustainable Manufacturing Terms. United States Environmental Protection Agency" [online] Available at: https://www.epa.gov/sustainability/glossary-sustainable-manufacturing-terms [Accessed: 10 October 2018]

Erwann, C. (2009) "Eco-labelling: A new deal for a more durable fishery management?", Ocean and Coastal Management, 52(5), pp. 250-257. https://doi.org/10.1016/j.ocecoaman.2009.03.003

Feucht, Y., Zander, K. (2018) "Consumers' preferences for carbon labels and the underlying reasoning. A mixed methods approach in 6 European countries", Journal of Cleaner Production, 178, pp. $740-748$. https://doi.org/10.1016/J.JCLEPRO.2017.12.236

Feunekes, G. I. J., Gortemaker, I. A., Willems, A. A., Lion, R., van den Kommer, M. (2008) "Front-of-pack nutrition labelling: Testing effectiveness of different nutrition labelling formats front-of-pack in four European countries", Appetite, 50(1), pp. 57-70. https://doi.org/10.1016/j.appet.2007.05.009

Fischer, C., Lyon, T. P. (2014) "Competing Environmental Labels", Journal of Economics and Management Strategy, 23(3), pp. 692-716. https://doi.org/10.1111/jems.12061

Gallastegui, G. I. (2002) "The Use of Eco-Labels: A Review of the Literature", European Environment, 12(6), pp. 316-331. https://doi.org/10.1002/eet.304

Grunert, K. G. (2005) "Food quality and safety: Consumer perception and demand", European Review of Agricultural Economics, 32(3), pp. 369-391. https://doi.org/10.1093/eurrag/jbi011

Grunert, K. G., Wills, J. M. (2007) "A review of European research on consumer response to nutrition information on food labels", Journal of Public Health, 15(5), pp. 385-399. https://doi.org/10.1007/s10389-007-0101-9

Grunert, K. G., Hieke, S., Wills, J. (2014) "Sustainability labels on food products: Consumer motivation, understanding and use", Food Policy, 44, pp. 177-189. https://doi.org/10.1016/j.foodpol.2013.12.001 
Gupta, G. (2017) "The Paradox of Sustainable Development: A Critical Overview of the Term and the Institutionalization Process", Periodica Polytechnica Social and Management Sciences, 25(1), pp. 1-7. https://doi.org/10.3311/PPso.8919

Hellström, T. (2007) "Dimensions of Environmentally Sustainable Innovation: the Structure of Eco-Innovation Concepts", Sustainable Development, 15(3), pp. 148-159. https://doi.org/10.1002/sd.309

Hepting, D. H., Jaffe, J., Maciag, T. (2014) "Operationalizing Ethics in Food Choice Decisions", Journal of Agricultural and Environmental Ethics, 27(3), pp. 453-469. https://doi.org/10.1007/s10806-013-9473-8

Hlédik, E., Lógó, E. (2017) "Product Experiences and Consumer Preferences Related to the Choice of Yogurt", Periodica Polytechnica Social and Management Sciences, 25(1), pp. 64-69. https://doi.org/10.3311/PPso.9331

ISO (2016) "ISO vol. 14021:2016 Environmental Labels and Declarations e Self-Declared Environmental Claims (Type II environmental labelling)", International Organization for Standardization, Geneva, Switzerland.

Jahn, G., Schramm, M., Spiller, A. (2005) "The Reliability of Certification: Quality Labels as a Consumer Policy Tool", Journal of Consumer Policy, 28(1), pp. 53-73. https://doi.org/10.1007/s10603-004-7298-6

Johansson-Stenman, O. (2018) "Animal Welfare and Social Decisions: Is It Time to Take Bentham Seriously?", Ecological Economics, 145, pp. $90-103$.

https://doi.org/10.1016/j.ecolecon.2017.08.019

Kerekes, S., Marjainé Szerényi, Zs., Kocsis, T. (2018) "Sustainability, Environmental Economics, Welfare", Budapesti Corvinus Egyetem, Budapest. [online] Available at: http://unipub.lib.uni-corvinus.hu/3658/1/sustainability.pdf [Accessed: 10 October 2018]

Kimenju, S. C., De Groote, H. (2008) "Consumer willingness to pay for genetically modified food in Kenya", Agricultural Economics, 38(1), pp. 35-46. https://doi.org/10.1111/j.1574-0862.2007.00279.x

Koistinen, L., Pouta, E., Heikkilä, J., Forsman-Hugg, S., Kotro, J., Mäkelä, J., Niva, M. (2013) "The impact of fat content, production methods and carbon footprint information on consumer preferences for minced meat", Food Quality and Preference, 29(2), pp. 126-136. https://doi.org/10.1016/j.foodqual.2013.03.007

Kotler, P., Bliemel, F. (2001) "Marketing-Management", 10th ed., Shaffer-Poeschel Verlag, Stuttgart, Germay.

Lang, T., Heasman, M. (2015) "Food Wars: The Global Battle for Mouths, Minds and Markets", 2nd ed., Routledge, London, UK. https://doi.org/10.4324/9781315754116

Leire, C., Thidell, A. (2005) "Product-related environmental information to guide consumer purchases - a review and analysis of research on perceptions, understanding and use among Nordic consumers", Journal of Cleaner Production, 13(10-11), pp. 1061-1070. https://doi.org/10.1016/j.jclepro.2004.12.004

Loureiro, M. L., Hine, S. (2002) "Discovering Niche Markets: A Comparison of Consumer Willingness to Pay for Local (Colorado Grown), Organic, and GMO-Free Products", Journal of Agricultural and Applied Economics, 34(3), pp. 477-487. https://doi.org/10.1017/S1074070800009251
Loureiro, M. L., McCluskey, J. J., Mittelhammer, R. C. (2001) "Assessing Consumer Preferences for Organic, Eco-labeled, and Regular Apples", Journal of Agricultural and Resource Economics, 26(2), pp. 404-416.

Manzini, R., Accorsi, R. (2013) "The new conceptual framework for food supply chain assessment", Journal of Food Engineering, 115(2), pp. 251-263. https://doi.org/10.1016/j.jfoodeng.2012.10.026

Napolitano, F., Pacelli, C., Girolami, A., Braghieri, A. (2008) "Effect of Information About Animal Welfare on Consumer Willingness to Pay for Yogurt", Journal of Dairy Science, 91(3), pp. 910-917. https://doi.org/10.3168/jds.2007-0709

Nelson, P. (1970) "Information and Consumer Behaviour", Journal of Political Economy, 78(2), pp. 311-329.

Noussair, C., Robin, S., Ruffieux, B. (2004) "Do Consumers Really Refuse to Buy Genetically Modified Food?" The Economic Journal, 114(492), pp. 102-120. https://doi.org/10.1046/j.0013-0133.2003.00179.x

Panainte, M., Inglezakis, V., Caraman, I., Nicolescu, M. C., Mosneguţu, E., Nedeff, F. (2014) "The evolution of eco-labeled products in Romania", Environmental Engineering and Management Journal, 13(7), pp. $1665-1671$. https://doi.org/10.30638/eemj.2014.184

Prieto-Sandoval, V., Alfaro, J. A., Mejía-Villa, A., Ormazabal, M. (2016) "ECO-labels as a multidimensional research topic: Trends and opportunities", Journal of Cleaner Production, 135, pp. 806-818. https://doi.org/10.1016/j.jclepro.2016.06.167

Princen, T. (1997) "The shading and distancing of commerce: When internalization is not enough", Ecological Economics, 20(3), pp. 235-253. https://doi.org/10.1016/S0921-8009(96)00085-7

Röös, E., Tjärnemo, H. (2011) "Challenges of carbon labelling of food products: a consumer research perspective", British Food Journal, 113(8), pp. 982-996. https://doi.org/10.1108/00070701111153742

Schneider, F., Kallis, G., Martinez-Alier, J. (2010) "Crisis or opportunity? Economic degrowth for social equity and ecological sustainability. Introduction to this special issue", Journal of Cleaner Production, 18(6), pp. 511-518. https://doi.org/10.1016/J.JCLEPRO.2010.01.014

Steffen, W., Richardson, K., Rockström, J., Cornell, S. E., Fetzer, I., Bennett, E. M., Biggs, R, Carpenter, S. R., de Vries, W., de Wit, C. A., Folke, C., Gerten, D., Heinke, J., Mace, G. M., Persson, L. M., Ramanathan, V., Reyers, B., Sörlin, S. (2015) "Planetary boundaries: Guiding human development on a changing planet", Science, 347(6223), p. 1259855. https://doi.org/10.1126/science.1259855

Süle, M. (2012) "Advertising effects vs. consumer consciousness Results of an empirical study", Periodica Polytechnica Social and Management Sciences, 20(2), pp. 91-103. https://doi.org/10.3311/pp.so.2012-2.04

Takeuchi, K. (2017) "Celebrating 10 years of Sustainability Science journal", Sustainability Science, 12(4), p. 505. https://doi.org/10.1007/s11625-017-0434-4

Terrachoice (2010) "The sins of Greenwashing. Home and Family Edition", [online] http://sinsofgreenwashing.com/index35c6.pdf [Accessed: 10 October 2018] 
Thøgersen, J., Nielsen, K. S. (2016) "A better carbon footprint label", Journal of Cleaner Production, 125, pp. 86-94. https://doi.org/10.1016/J.JCLEPRO.2016.03.098

van den Bergh, J. C. J. M. (2010) "Externality or sustainability economics?", Ecological Economics, 69(11), pp. 2047-2052.

https://doi.org/10.1016/j.ecolecon.2010.02.009

Van Kleef, E., Dagevos, H. (2015) "The Growing Role of Front-ofPack Nutrition Profile Labeling: A Consumer Perspective on Key Issues and Controversies", Critical Reviews in Food Science and Nutrition, 55(3), pp. 291-303.

https://doi.org/10.1080/10408398.2011.653018

Vanclay, J. K., Shortiss, J., Aulsebrook, S., Gillespie, A. M., Howell, B. C., Johanni, R., Maher, M. J., Mitchell, K. M., Stewart, M. D., Yates, J. (2011) "Customer Response to Carbon Labelling of Groceries", Journal of Consumer Policy, 34(1), pp. 153-160. https://doi.org/10.1007/s10603-010-9140-7

Vecchio, R., Annunziata, A. (2015) "Willingness-to-pay for sustainability-labelled chocolate: an experimental auction approach", Journal of Cleaner Production, 86, pp. 335-342.

https://doi.org/10.1016/j.jclepro.2014.08.006
Verbeke, W. (2005) "Agriculture and the food industry in the information age", European Review of Agricultural Economics, 32(3), pp. $347-368$.

https://doi.org/10.1093/eurrag/jbi017

Wagner, M. (2008) "Empirical influence of environmental management on innovation: Evidence from Europe", Ecological Economics, 66(2-3), pp. 392-402. https://doi.org/10.1016/j.ecolecon.2007.10.001

Weinrich, R., Spiller, A. (2016) "Developing food labelling strategies: Multi-level labelling", Journal of Cleaner Production, 137, pp. $1138-1148$.

https://doi.org/10.1016/j.jclepro.2016.07.156

Zhao, R., Geng, Y., Liu, Y., Tao, X., Xue, B. (2018) "Consumers' perception, purchase intention, and willingness to pay for carbon-labeled products: A case study of Chengdu in China", Journal of Cleaner Production, 171, pp. 1664-1671.

https://doi.org/10.1016/j.jclepro.2017.10.143 